\title{
From the Orthodox to the Modern, Realistic Classification of Bacteria
}

\author{
F. KAUFFMANN
}

Statens Seruminstitut, Copenhagen, Denmark

\begin{abstract}
The principles of the Kauffmann-White-Schema, of the species definition, and
\end{abstract} of the modern, realistic classification, published by the author, are summarized.

I. The Kauffmann-White-Schema. Today, there are two different classifications of bacteria: the orthodox and the modern, realistic. The orthodox classification is represented by Bergey's Manual of Determinative Bacteriology and many taxonomic publications, and the modern classification was started by the first report of the International Salmonella Subcommittee in 1934 (8). The members of this Subcommittee of the Nomenclature Committee of the International Society for Microbiology were the late H. Schütze, Lister Institute, London (chairman), the late W. M. Scott, Ministry of Health, London, the late P. Bruce White, National Institute for Medical Research, London, F. Kauffmann, Statens Seruminstitut, Copenhagen, and the late R. St. John-Brooks, National Collection of Type Cultures, London (secretary).

In the orthodox classification the "species" are not defined correctly, as only biochemical (mostly fermentative) methods are used, whereas in the modern classification the real species are defined both biochemically and serologically.

In the report of the International Salmonella Subcommittee (8), the following appeared:

The classification employed (The KauffmannWhite-Schema) is based upon the taxonomic schema finally presented by Kauffmann in 1931, which is in itself a re-examination and amplification of the pioneer work of Schütze, Bruce White, Scott and others. The species recognised are taken in the order followed by Kauffmann, with a few minor alterations and additions. The names employed are those finally approved by the subcommittee. They are followed, in each case, by brief particulars of first isolation and by a list of the principal synonyms employed in the literature. The antigenic structure is indicated according to Kauffmann's method.

The Report of the Subcommittee ended with the following statement:

This belief in serology as the ultimate criterion in the taxonomy of the group is the consequence of the experience of the very great practical services serology has rendered, turning a field full of uncertainties and pitfalls into one in which identification has become easy, certain and closely correlated with pathology and epidemiology. It is not suggested that the classification of bacteria should be based on serological criteria alone. The true field of serology lies in differentiating between bacteria that are plainly related to each other on other grounds (morphology or general bionomics). Within a group so recognised the serological differences are so definite as to be valid in erecting species.

II. The species definition. I presented the following definition in 1961 (2): "A species is a group of related sero-fermentative phagetypes."

In a later publication (3), I gave as an example the species Salmonella typhimurium, one of the largest species, consisting of many serofermentative phage types. All cultures of $S$. typhimurium belong to the serotype $1,4,5,12$ : i: 1,2 , but occur in four different serotypes: $1,4,5,12: \mathrm{i}: 1,2 ; 4,5,12: \mathrm{i}: 1,2 ; 1,4,12: \mathrm{i}: 1,2 ;$ and $4,12: 1: 1,2$. These serotypes are combined in the Kauffmann-White-Schema to $1,4,5,12: \mathrm{i}: 1,2$ for simplification.

Each of these serotypes can be divided into different fermentative types (or biotypes), such as into inositol-positive or -negative types, etc. Further, each of these sero-fermentative types can be divided into several phage types. Therefore, the fundamental elements of the species are the exactly defined serofermentative phage types, for example, serotype 4,5,12:i: 1,2 ; biotype 20 ; phage type 1 .

In addition to the above two papers on the species definition, it may be mentioned that I used the designation "Sero-, Bio- und PhagTypen" in 1957 (1).

III. The modern, realistic classification. In 1971 I presented the following (4):

1. On the basis of a new theory of reality those concerned with classification should take into consideration the categories or taxa occurring in nature, i.e. the species, however, not abstract ideas. 
2. The species defined as groups of related sero-, bio-, phago-types are the only categories or taxa occurring in nature, so that the entire classification is orientated not vertically, but horizontally.

3. All other categories are only artificial concentrations of species for the purpose of better understanding, they do not exist in nature and are, therefore, of little importance.

4. Classification is primary and decisive so that nomenclature does only play a secondary and subsidiary role.

5. Classification must not be determined by national or international committees since scientific problems should not be decided by majority decisions of such committees.

6. Without serology no useful classification and without classification no useful nomenclature.

In a following paper (5), a new simplied nomenclature was published, and a new, simplified Bacteriological Code according to the modern, realistic classification was proposed. The following points may be stressed:

The beginning of priority for scientific names should be the year 1900 , not 1753 .

Scientific names should be used only for serologically defined species; otherwise only common names should be given.

The majority of species given in the literature (e.g., in Bergey's Manual of Determinative Bacteriology) should be cancelled, since species can be established only if an exact, serological diagnosis is performed.

The name of a species does not indicate the characteristics of the species, but only supplies a means of referring to it. Therefore, species are designated not only by names, but also by antigenic formulas. Names and designations should not be changed without serious motives.

The above-mentioned ideas were extended in other publications $(6,7)$. In these papers the fundamental principles are summarized as follows: The only category or taxon occurring in nature is the species; it is a reality. The species is a group of related sero-, bio-, and phagotypes, i.e., a group of related cultures defined by their serological, biochemical (or fermentative), and other properties. Therefore, the species is not identical to a serotype. There are no "subspecific" or "infrasubspecific" categories below the species. The sero-, bio-, and phagotypes are not three different categories, but only three different properties of the same organism. All the other categories or taxa, such as subgenus, genus, tribus, familia, etc., are not realities in nature, but are artificial collections of species used to facilitate the general view; they are "creations of our mind." Therefore, the classification is orientated in a horizontal, not in a vertical, way.

This theory of reality is valid not only for bacteria, but also for all other living organisms; it is a general biological principle.

We cannot establish a family tree and a hierarchical system; we can only analyze the species occurring in nature. The species diagnosis cannot be done by chemical analysis of antigens, immunoelectrophoresis, etc., but only by the classical, serological method. We do not aim at a complete antigenic analysis, but only at a useful instrument by which to diagnose species.

\section{REPRINT REQUESTS}

Address reprint requests to: Professor Dr. F. Kauffmann, Statens Seruminstitut, Amager Boulevard 80, Dk-2300 Copenhagen S, Denmark.

\section{LITERATURE CITED}

1. Kauffmann, F. 1957. Das Kauffmann-WhiteSchema. Ergeb. Mikrobiol. Immunitaetsforsch. Exp. Ther. 30:159-216.

2. Kauffmann, F. 1961. The species-definition in the family Enterobacteriaceae. Int. Bull. Bacteriol. Nomencl. Taxon. 11:5-6.

3. Kauffmann, F. 1963. On the species-definition. Int. Bull. Bacteriol. Nomencl. Taxon. 13:181-186.

4. Kauffmann, F. 1971. Eine neue, realistische Klassifikation. Zentralbl. Bakteriol. Parasitenk. Infektionskr. Hyg. Abt. 1 Orig. A 217:198-201.

5. Kauffmann, F. 1971. Eine neue vereinfachte Nomenklatur. Zentralbl. Bakteriol. Parasitenk. Infektionskr. Hyg. Abt. 1 Orig. A 217:202-205.

6. Kauffmann, F. 1971. Die moderne Klassifikation und Nomenklatur der Bakterien. Curr. Top. Microbiol. Immunol. 56:1-12.

7. Kauffmann, F. 1973. On the realistic classification and evaluation of serology. Acta Pathol. Microbiol. Scand. Sect. B 81:198-202.

8. Salmonella subcommittee. 1934. The genus Salmonella Lignières, 1900. J. Hyg. 34:333-350. 